\title{
The Relationship between Students' ICT Use and Their School Performance: Evidence from PISA 2015 in the Czech Republic
}

\author{
Libor Juhaňák, Jiří Zounek, Klára Záleská, \\ Ondřej Bárta, Kristýna Vlčková \\ Masaryk University, Faculty of Arts, Department of Education Sciences
}

\begin{abstract}
In the last decades, Information and Communication Technologies (ICT) have become recognized as an important and integral part of life as well as education. At the same time, the implementation and use of ICT in schools is one of the longstanding strategic objectives and priorities in education policy in the Czech Republic. However, up to now, rather little attention has been paid to the research in the use of digital technologies in Czech schools with regard to students' performance. The purpose of the present study is therefore to investigate various ICT-related factors associated with school performance of students in the Czech Republic. Specifically, this study takes data from the latest Programme for International Student Assessment (PISA 2015) to determine the extent to which availability and use of ICT in school and at home is related to students' educational achievements. Results of this study can provide substantial implications and suggestions for national ICT policies (especially the Strategy for Digital Education until 2020).
\end{abstract}

Keywords: ICT availability; ICT use; school performance; PISA 2015

Information and communication technologies (ICT) ${ }^{1}$ are undoubtedly one of the key elements in current education. The importance of ICT for education in the Czech Republic (CR) has been declared in current strategic documents, not only within the Strategy for digital education until 2020 (MŠMT, 2014) but also for instance in the concept Digital Czechia v. 2.0, a pathway to digital economy (MPO, undated document). The latter document declares that the state perceives the inevitability of ICT becoming integrated in the whole process of learning at primary schools and in all individual subjects. In an overwhelming majority of schools in CR, however, digital technologies are already playing an important role not only in teaching and learning but also in everyday school bureaucracy (ČŠI, 2017b). Last but not least, ICT in education is perceived as important also in current pedagogical research. Evidence of this was provided for example by the 2017 conference of the Czech Education Research Association, whose theme was the influence of technologies in education and educational research (Michek, Vondroušová, \& Vítová, 2017). Another example

1 The term is used here to refer to any technologies and technological tools enabling communication and working with information in an electronic form, see e.g. Zounek and Šed'ová (2009). In the context of this study, similar terms such as information technologies, digital technologies or modern technologies are treated as synonyms. 
38 is the 2015 specialized issue of Pedagogika focusing on ICT in education and the 2018 specialized issues of Pedagogika and Studia paedagogica. ${ }^{2}$

Despite this, digital technologies in education have not been considered as a factor enough in $\mathrm{CR}$ in the long run, neither in educational research nor in educational policies. As Zounek and Tưma (2014) have shown in their analysis focusing on four main Czech journals of educational research, ${ }^{3}$ these journals published only nine empirical studies dealing with ICT between 1990 and 2012. The same is true of educational policies as here, too, systematic monitoring of the operation of the Czech educational system - to be undertaken through research and/or evaluation activities at the national level - is missing (see Potužníková, Lokajičková, \& Janík, 2014; Straková, 2009). The situation in ICT is similar, as has been remarked even in the Strategy for digital education (MŠMT, 2014), where insufficient research in and monitoring of the implementation of digital technologies in education represents one of the key topics. Therefore, although there is no doubt that digital technologies have been influencing Czech education for a rather long period of time, their influence on education and the educational system has paradoxically been under-researched.

This study therefore aims to contribute to a better understanding of the role of ICT in student learning and education; more specifically, we are focusing on understanding the relationship between availability and use of digital technologies (both in school and at home) and students' school performance. Results of such analysis may yield important scholarly knowledge as a contribution to the professional debate on the influence of digital technologies on student learning. Also, our findings can partly be regarded as feedback or evidence for educational policies to rely on in making decisions concerning future directions in ICT use and implementation in education as well as in planning research and/or evaluation activities at the national or international level.

\section{ICT in Czech educational policies and research}

This part of the paper will first map ICT in Czech educational policies and then move on to the current situation in ICT availability and use by students at school and at home as seen through the lenses of national and international surveys. The last part of the chapter will provide an outline of research focusing directly on the link between ICT availability and use and students' school achievements.

\subsection{Czech educational policies and ICT}

Educational policies paid attention to integration of "modern" technologies in education as early as in the 1980s (in the socialist Czechoslovakia of then), when in 1985 the strategic document titled Long-term comprehensive programme of elec-

2 For more details see pages.pedf.cuni.cz/pedagogika, www.studiapaedagogica.cz.

3 These were Orbis scholae, Pedagogická orientace, Pedagogika and Studia paedagogica. 
tronization in education and upbringing in the educational system was adopted by the government (Caha, 1986; Zounek \& Šed'ová, 2009). The Velvet Revolution of 1989 put an end to any activities associated with this document. In the 1990s a clearly formulated national educational policy or vision for future development to accentuate the issue of modern technologies was missing, despite the fact that the 1990s were a period when ICT were becoming important not only in education.

Educational policies turned their attention to ICT as late as at the turn of the millennium, with the government approving the Concept of National Information Policy in Education in April 2000. The Concept's goals, beyond equipping schools with computers and connecting schools to the internet, were educating teachers in using ICT and developing digital (electronic) educational programmes and information resources. The process of implementation of the Concept was however lagging behind the plan from its very first year, indicating that the worry that the project was focusing too much on technologies themselves and neglecting their integration in classroom activities or student learning was justified (Punar, 2008). In spite of that, this was a period when information technologies became reality in most Czech schools. In 2008, a strategic document called Developmental Strategy on ICT in Education for 2009-2013 was created, with the goal of initiating again and setting up centralized support to the implementation of digital technologies in education. As early as in 2009 it however turned out that due to the financial possibilities of and situation in the Ministry of Education the proposed programme could not be implemented as planned. Introducing digital technologies to schools nevertheless went on to some extent. Evaluation of the implementation of digital technologies in schools and the efficiency of means expended however remained entirely unsatisfactory (see MŠMT, 2014).

The latest educational policies document dealing with ICT so far has been the Strategy for digital education until 2020, which sets out three principal goals: 1) open up education to new methods and ways of learning mediated by digital technologies; 2) improve students' competencies in using information and digital technologies; and 3) develop computational thinking in students (see MŠMT, 2014). These goals should be achieved through a set of measures structured within seven intervention directions, including the following ones: setting up a non-discriminating approach to digital educational resources, guaranteeing conditions for developing digital literacy in students and teachers, building up educational infrastructure and supporting innovative approaches and increasing public informedness regarding educational technologies. What can be regarded as a crucial statement is the explicit acknowledgment of systematic data collection and monitoring of the current state of implementation of digital technologies in education (including educational research). ${ }^{4}$ The existing evaluations of the strategy in progress (see MŠMT, 2017, 2018)

4 This has been addressed by several measures, primarily Measure 5.2 (Support to educational research of the use of digital technologies), Measure 5.3 (Support to regular data collection, situation monitoring and use of digital technologies in education), and Measure 5.4 (Improving 
40 unfortunately suggest that the implementation of some measures is, again, lagging behind the plan.

It can be summarized that the implementation of ICT-supporting activities in the Czech environment has been considerably non-systemic and irregular (Schoolnet, 2015) and evaluation activities and monitoring so far have been entirely unsatisfactory. Positive trends however also merit a mention: Czech educational policies have gradually transitioned in terms of their priorities from emphasis on providing the largely technological infrastructure for schools to developing teacher education and student competencies within ICT and, above all, support to evaluation and research of ICT use in education (see the first explicit mention in the Strategy for digital education until 2020).

\subsection{An overview of current situation in ICT in Czech schools and lives of students}

As has been suggested in the introduction, this study focuses on ICT availability and use by students in the school environment as well as at home. Focusing our attention first on schools, the most up-to-date information on equipment and use of digital technologies in Czech schools can be drawn from the specialized report of the Czech School Inspectorate (CSI) from September 2017 (ČŠI, 2017b). It presents results of inspection activities of the Inspectorate focusing on identifying conditions for using digital technologies and it has also been included in the Inspectorate's annual report published at the end of 2017 (ČŠl, 2017a). The inspection activities were carried out throughout the school year 2016/2017 through an on-line questionnaire filled in by headmasters of all kindergartens, all primary schools, all secondary schools and higher vocational schools. The specialized report dealt, among other things, with physical and personnel prerequisites for working with digital technologies in schools and with teaching with the support of ICT. In connection with the Strategy for digital education until 2020, part of the data on the use of digital technologies in Czech schools has been made available in the form of so-called open data. ${ }^{5}$

The data presented in the specialized report is, unfortunately, rather brief, 6 not providing a comprehensive overview of the current state in the Czech Republic. It nevertheless offers some interesting, even though basic, information. It for instance turns out that ICT have been an everyday part of the life of virtually all schools in $\mathrm{CR}$, with $99 \%$ of big primary schools, ${ }^{7}$ secondary schools and higher vocational schools

information and knowledge-base in the use of digital technologies, developing digital literacy and thinking in line with information science). For more details, see MŠMT (2014).

5 See website Statistická data o ICT ve školách v podobě otevřených dat [Statistical data on ICT in schools in the open-data form] accessible through the website of the Ministry of Education (www.msmt.cz/vzdelavani/skolstvi-v-cr/statistika-skolstvi/otevrena-data).

6 Even when compared with the Czech School Inspectorate's annual report for 2011/2012 (ČŠI, 2013), where ICT are paid considerably more attention. It is also necessary to bear in mind that CSI does not conduct scientific research.

7 I.e. primary schools with over 150 students. 
using an information system of some kind to deal with the administrative agenda and having a webpage of their own. Small primary schools and kindergartens are less well equipped with and less good at using technologies but nevertheless around $90 \%$ of kindergartens and smaller primary schools have a website of their own and an information system. Another rather positive fact is that most schools have an ICT development plan which they subject to updates (ČŠI, 2013, 2017b), which might play a positive role in how often and how teachers use ICT during classroom exposure.

Although the equipment and infrastructure may seem sufficient for the present time, the relatively fast ageing proves to be a problem. The Czech School Inspectorate even warns in its specialized report from 2017 quoted above that the share of schools with dated technologies has been growing considerably, which may consequently mean a deterioration of the prerequisites for ICT-supported teaching. ${ }^{8}$ Another problem is insufficient personnel basis for ICT-supported teaching, with the position of an ICT administrator often missing (it exists in $17.8 \%$ kindergartens and $35.1 \%$ of primary schools). This means, among other things, that digital technologies administration in schools is often the responsibility of the ICT teacher or ICT coordinator, leaving them with less time for their own work - coordinating ICT in the school and providing methodological support for teachers. The Czech School Inspectorate thus concludes its report with a rather alarming statement that the minimal standards of quality of conditions for using digital technologies have been met by $5 \%$ of small primary schools, nearly $10 \%$ of big primary schools and approximately $20 \%$ of secondary schools and higher vocational schools (ČŠI, 2017b).

Turning our attention to the accessibility of ICT in home environment for Czech 15-year-old students, outputs by the Czech Statistical Office (CSO) may be used, focusing generally on how Czech households are equipped with digital technologies, or ILSA (International Large-Scale Assessments) findings - covering also the Czech Republic and providing necessary information 9 - may also be used. According to the CSO, in 2017 there was a PC in $94.6 \%$ of households with children younger than 15 and $95.9 \%$ of households with children could access the internet. The PISA 2012 survey (OECD, 2015) arrived at similar results. The ensuing report states that in CR, more than $98 \%$ of students could use a PC at home in 2012 and slightly less $(97.4 \%)$ could access the internet from home. It may therefore be inferred that the basic level of ICT availability in home environment is more or less universal for Czech students. Differences in ICT availability based on socioeconomic status do still exist but the problem seems to be less pronounced than in the past (Basl, 2010; OECD, 2005).

8 E.g. according to results from 2009, more than a half of computers (56\%) for classroom use were younger than 5 years; now less than 10\% meet this condition (ČŠl, 2009, 2017b).

9 These were primarily ICLIS and PISA surveys. ICILS survey is coordinated by IEA, focusing on computer and information literacy. Its most recent run was in 2013, with students of Grade 8 of primary schools and corresponding grades of 8-year and 6-year gymnasiums as the tested group. The PISA survey is implemented by OECD and besides the main area of focus, measurement of educational outcomes, it partly also focuses on issues such as ICT in education. The most recent survey was conducted in 2015, with 15-year-old students as the tested group. For more information on international research in education see e.g. Soukup (2012), Basl (2014) or Straková (2016). 
To conclude this section, we will focus on how 15-year-old students in CR use digital technologies, not only at school but also beyond school. There is, however, a shortage of data for CR coming from national (topic-related) research and only results from international ICILS and PISA surveys can thus be used. Those suggest that within an international comparison, Czech students are generally among the frequent ICT users, both at school and at home within their leisure-time activities. The time spent online outside of school does not widely differ depending on students' socioeconomic status (ČŠI, 2016). ${ }^{10}$ At the same time, ICT use in school has been growing over the recent years. For all types of activities falling within the index of ICT use at school, ${ }^{11}$ the OECD averages for 2009 to 2012 have shown a growing trend in terms of students reporting they were involved in the activity at least once per week (OECD, 2011, 2015). PISA 2012 survey was the first to focus on how much time 15-year-old students spend online, differentiating between school and home and between using ICT on weekdays and over the weekend. According to PISA 2012, approximately $36 \%$ of Czech students spend four or more hours online, which is a value exceeding the international average. Even during the working days, Czech students spend more time online in their homes than the average OECD value is; a comparison with PISA 2015 data shows that the amount of time spent online has recently been growing (OECD, 2015, 2017a). In contrast, Czech students spend less time online at school compared with the OECD average.

\subsection{ICT in connection to students' school performance}

To shift attention to ICT in connection to students' educational outcomes, in CR only some information is available, namely only information based on PISA survey data. It is worth mentioning for instance PISA 2006 secondary analysis (Kubiatko \& Vlčková, 2010), dealing with the relationship between ICT use by students and their performance in science. The authors of the analysis have found a positive relationship between ICT use and knowledge of Czech 15-year-olds in science. For instance, students who used PCs for educational activities more often, performed better. Similarly, the longer the experience of using a PC, the better the students performed. By contrast, the results of the secondary analysis by the Czech School Inspectorate using PISA 2012 data (Č̌̌l, 2016) were less optimistic. The analysis focused on ICT use in school and it turned out that both for primary schools and for 8-year and 6-year gymnasiums (i.e. general secondary schools of the lyceum type) it was true that students in less successful schools used ICT more widely, and, conversely, that students from very successful schools used ICT the least. The international PISA 2012 survey (OECD, 2015) reached similar conclusions, also finding rather a negative relationship

10 Certain differences however concern activities pursued. Students with lower socioeconomic status report activities such as acquisition of practical information online or reading online less often while the frequency of activities such as gaming does not seem to be influenced by the socioeconomic status of the student's family.

11 For more information on the index see the section on methodology (below). 
between ICT use (at school) and students' performance. Mathematical and reading skills are generally lower in countries with higher shares of students using ICT in school. PISA results also suggest that students in countries focusing on introducing PCs into schools between 2003 and 2012 more than in other countries performed less well than students elsewhere. Overall the results of PISA 2012 (OECD, 2015) may be summarized by saying that as for the effect of ICT on student performance, there is a negative rather than positive (even though rather weak in some cases) relationship between the use of ICT and learning outcomes.

In the Czech Republic, unfortunately, more detailed research of the effect of ICT use on students' outcomes is missing. One may resort to results of international research dealing with the issue but it never fully considers the context of the Czech Republic, and cannot therefore replace missing national research fully. Research focusing on students' school performance has, for instance, shown repeatedly that the Czech educational system is characterized by a relatively strong link between the socioeconomic status and cultural capital of the family on the one hand and the student's school performance on the other (Matějů \& Straková, 2006; Matějů, Straková, \& Veselý, 2010; Potužníková et al., 2014; Straková, 2009). This means that children from families with higher cultural and socioeconomic status perform better. The Czech educational system is thus not sufficiently capable of levelling out the differing input potential students are carrying over from their home environments. This is also connected to the big gap in student performance between different types of school. While students studying in Czech gymnasiums score among the best in the international comparison, students in vocational training score among the worst in international comparisons and often are unable to achieve even the basic qualification level (Matějů et al., 2010; Palečková, Tomášek, \& Basl, 2010; Sucháček, 2014). Moreover, this gap seems to deepen (Straková, 2010). Gender also proves an important factor influencing learning outcomes of students in CR. Girls in CR are generally better at reading while boys are better in maths and sciences (Potužníková et al., 2014). At the same time, as Matějů and Simonová (2013) show, girls are at an advantage in CR to some extent as, for instance, they achieve better grades in maths despite having less good mathematical skills than boys according to PISA results. This and other Czech specifics related to students' school performance may also be reflected in whether and how the availability and use of ICT relate to student achievements.

International research addressing ICT in education and specifically in connection to school performance is relatively abundant. Clear answers concerning the effect of ICT on learning outcomes (whether positive or negative) are however rather scarce. The great heterogeneity and even contradictory nature of the results may be ascribed to the varying focus of the studies, the considerable complexity of the topic of ICT in education or the application of a wide range of methodologies (Biagi \& Loi, 2013; Cox \& Marshall, 2007). Fundamental lack of clarity besets even very basic questions concerning the effect of ICT on learning outcomes. The research includes studies finding positive effect of ICT on learning outcomes (Erdogdu \& Erdogdu, 
44 2015; Spiezia, 2010) as well as studies finding the effect to be negative (Leuven, Lindahl, Oosterbeek, \& Webbink, 2007). Other studies find the effect to be non-existent (Falck, Mang, \& Woessmann, 2017; Wittwer \& Senkbeil, 2008) or present mixed results (Biagi \& Loi, 2013; Comi, Argentin, Gui, Origo, \& Pagani, 2017; Luu \& Freeman, 2011; Ponzo, 2011; Skryabin, Zhang, Liu, \& Zhang, 2015).

Focusing on ICT availability first, for instance Erdogdu \& Erdogdu (2015) may be mentioned, who come up with the finding that the availability of the internet, whether at home or in school, has a positive effect on learning outcomes of students. However already an older study by Woessmann \& Fuchs (2014) has shown that the relation between ICT availability and school performance may turn the other way round as soon as other relevant factors are taken into consideration. In their study, including variables concerning family background and school characteristics resulted in turning the originally positive correlation into a negative one for PC availability at home and into a non-significant correlation for PC availability at school. As for ICT use by students, Ponzo (2011) has identified a significant positive relationship between students' learning outcomes and the frequency of using the PC as an educational tool at home but mentions also the negative effect of PC use in school on learning outcomes. Biagi \& Loi (2013) also present mixed results, finding a positive relationship of some ICT-based activities with learning outcomes but a negative relationship for other activities. All of the above stated shows that the correlation between ICT availability and use, whether at school or at home, is not straightforward and may be influenced by a number of other factors. This presents the obvious requirement for researchers to be aware of the complexity of this relationship and choose appropriate analytical procedures. This also indicates with increasing urgency the need to rely not only on quantitative indicators of ICT use (see Lei, 2010) but monitor and consider in analyses other relevant ICT-related factors and variables.

\section{Research problem}

As has already been stated, modern technologies are a topical issue in the context of Czech educational policies. Despite this, many questions in ICT-in-education research and monitoring remain unanswered. Even data concerning the use of ICT obtained within International Large-Scale Assessments remain largely unaddressed, the reports and secondary analyses published by the Czech School Inspectorate being a rather rare exception. Lack of clarity also characterizes the international research in digital technologies in education, where the findings of research in the effect of technologies on students' learning outcomes tend to be mixed and contradictory. This study therefore aims to reach a better understanding of how ICT availability and use by Czech students in school and outside of school is reflected in their school performance. We would like to contribute to a better understanding of these issues, lessening the "white spots" in the map of this topic. 
Availability of ICT to students is naturally influenced both by the family environment and the environment at school. Therefore, we want to focus on access to modern technological equipment in schools as well and we want to find out whether the level of this equipment plays a role in students' learning outcomes. One of the key elements of the use of digital technologies in contemporary society is using the internet. The analysis will therefore specifically focus also on time spent by 15-year-olds online. Finally, we seek to determine how students' learning outcomes reflect their interest in modern technologies and their perceived competence and autonomy in using them.

We have therefore formulated the individual research questions as follows:

1) To what extent is the availability of ICT to students in school and at home related to their school performance?

1a) To what extent is the level of ICT equipment in schools related to students' school performance?

2) To what extent is the use of ICT by students in school and at home related to their school performance?

2a) To what extent is the frequency of using the internet by students in school and at home related to their school performance?

3) To what extent is students' interest in using ICT related to their school performance?

4) To what extent is students' perceived autonomy and competence in ICT usage related to their school performance?

\section{Data and methodology}

\subsection{Sample and procedure}

The analyses are based on data from PISA 2015 (Czech dataset), specifically data concerning students' results in tests of mathematical (MATH), reading (READ) and science (SCIE) literacy, data from the student questionnaire (primarily the ICT Familiarity Questionnaire) and data from the school questionnaire.

The final sample contains data from 6812 students aged 15 to 16 (range = $15.3-16.3, M=15.8, S D=0.28,49.7 \%$ of girls) from 333 schools. ${ }^{12}$ In terms of schools, the data was collected in 144 primary schools (PS), 53 secondary vocational schools without maturate (SVS), 56 secondary technical schools with maturate (STS), 44 8-year and 6-year gymnasiums (G8-6) and 44 4-year gymnasiums (G4). The school data included $88.6 \%$ of state-funded schools and $9.6 \%$ of private or church-funded schools. For 6 schools in the dataset this piece of information was missing.

12 The analysis excluded 82 students from 11 practical and special schools. 


\subsection{Measures}

To answer the research questions formulated above, the research based the proxy indicator of school performance of students (i.e. the dependent variable) on students' performance in tests of mathematical, reading and science literacy. The analysis was conducted separately for mathematical, reading and science literacy, as the analyses have shown that there are certain differences as to the influence of the ICT-related variables on student performance between the individual areas.

Let us also remark that in PISA 2015 data, student performance in these areas is represented by 10 plausible values each (compared with only 5 plausible values in the previous runs). This fact was taken into account in an appropriate way by the analyses. ${ }^{13}$ Weight coefficients were also applied so that the calculations are correct with respect to the nature of PISA 2015 data.

\subsubsection{ICT availability}

As for ICT availability from student perspective, students' answers in the ICT Familiarity Questionnaire provide two indexes: one reflecting ICT availability in school (ICTSCH) and the other measuring ICT availability at home (ICTHOME). ${ }^{14}$ Questions of both kinds were formulated asking about selected devices and their availability at home or in school. The list of devices in both kinds of questions included options such as PC, laptop, mobile phone, or USB flash disk. Some devices were only listed in connection with school (such as the interactive whiteboard), others only in connection with home (such as the PlayStation). For each of the selected devices, students were choosing from among these options: Yes and I use it; Yes but I don't use it and No. The resulting index was calculated as a sum of the component items.

The questionnaire administered to school headmasters (school questionnaire) within PISA 2015 survey included several questions concerning ICT equipment available in the school (questions SC004Q01 through SC004Q07). Our research in ICT availability to students therefore also focused on the level of ICT equipment in school. We monitored five variables:

- Number of PCs per student. The variable was calculated using answers to question How many computers are approximately available to these students in your school for their learning?; the expression 'these students' refers to the previous question, focusing on the number of students in the grade under analysis, i.e. grade 9 in primary schools, grade 1 in secondary schools and 4-year gymnasiums and the corresponding grade in 8-year and 6-year gymnasiums. The number of computers listed thus did not have to correspond to the overall number of computers in the school; the question targeted the number of computers available to

13 As Soukup (2016) or Straková (2016) claim, the analyses have to be made for each of the plausible values separately, then calculating a mean value (the standard error is calculated from the variance of the individual values).

14 The abbreviation in the brackets is the reference to the given variable in PISA 2015 dataset. For more information on how individual indexes or scales were constructed see the OECD Technical Report for 2015. 
students in the grade under analysis. The construction of the variable excluded several instances of extreme values where the assumption was that the headmaster filling in the questionnaire considered the whole school instead of the grade in question.

- Number of portable PCs per student. This variable was similar to the one described above, the difference being that only portable computers (laptops) were to be considered. In this case, too, several extreme values were excluded from the dataset.

- Number of PCs per teacher. The variable was constructed using answers to the question How many internet-connected PCs are available in your school to teachers? The answers were related to the total number of teachers with a full-load employed by the school (question SC018Q01TA01 in the questionnaire).

- Number of interactive whiteboards in the school. The variable was based on the question How many interactive whiteboards are available in your school? (without further adjustments).

- Number of data projectors in the school. The variable was based on the question How many data projectors are available in your school?, again without any further adjustments.

Let us remark that due to the distribution of these five variables not being normal, each of the five variables was subjected to logarithmic transformation before being included in the model.

\subsubsection{ICT use}

PISA 2015 also measured ICT use by students both in school and at home. In domestic environment, it was further differentiated between ICT use in connection to school (i.e. primarily to prepare for classes) and ICT use for enjoyment and/or in one's leisure-time. ${ }^{15}$ This provided us with three indexes. The corresponding questions in the questionnaire focus on the frequency of using electronic devices, students choosing from among the following options: Never or hardly ever; Once or twice in a month; Once or twice a week; Almost every day; Every day. The individual indexes have been constructed using IRT modelling (OECD, 2017d).

- Students' use of ICT at school (USESCH). Examples of activities students responded to are, for instance: Chatting online at school; Playing simulations at school or Using school computers for group work and communication with other students. The item reliability of the index for CR is 0.887 (Cronbach's alpha).

- Students' use of ICT outside of school for school work (HOMESCH). Examples of activities are: Browsing the Internet for schoolwork; Using email for communication with other students about schoolwork or Doing homework on a computer. The item reliability of the index for CR is 0.901 .

15 We believe that this differentiation should be applied also when ICT use in school is studied, as the use by students in school itself does not guarantee that ICT are used primarily for school purposes. 
- Students' use of ICT outside of school for leisure activities (ENTUSE). Examples of activities are: Chatting online; Browsing the Internet for fun; Playing online games via social networks etc. The item reliability of the index for CR is 0.810 .

Besides the above-listed indexes, we have analysed data from questions focusing specifically on the frequency of using the internet. These are three questions in the questionnaire asking about the time usually spent by students online (IC005Q01TA, IC006Q01TA, IC007Q01TA). The first one focuses on the school environment, the second on the home environment during an average weekday, and the third one on the home environment during the weekend (average Saturdays and Sundays). With all three questions, students select from among seven options: No time, 1-30 minutes per day; 31-60 minutes per day; Between 1 hour and 2 hours per day; Between 2 hours and 4 hours per day; Between 4 hours and 6 hours per day and More than 6 hours per day.

For the purposes of the analysis the number of categories for each variable was reduced to 5 , considering the number of cases within each category (and joining primarily those categories which contained few cases). For the variable characterizing the use of internet in school, the following five levels were distinguished in the final analysis: No time; 1-30 minutes per day; 31-60 minutes per day; Between 1 hour and 4 hours per day and More than 4 hours per day while with variables concerning time spent online at home, the following levels were distinguished: Between no time and 30 minutes per day; Between 31 minutes and 2 hours per day; Between 2 hours and 4 hours per day; Between 4 hours and 6 hours per day and More than 6 hours per day.

\subsubsection{ICT interest and ICT in students' social life}

PISA 2015 survey measured interest in ICT in general as well as to what extent ICT was integrated into the lives and social interactions of 15 -year-old students. In both cases, the question in the questionnaire was exploring the degree of agreement or disagreement with selected statements concerning students' interest in ICT. Students scored each statement on a four-point Likert scale, the options ranging from Strongly disagree to Strongly agree. Let's add that PISA 2015 was the first occasion for these questions to be used in a PISA survey. ${ }^{16}$

- Students' ICT interest (INTICT). Examples of statements students responded to are: I like using digital devices; I am really excited discovering new digital devices or applications or I really feel bad if no internet connection is possible. The item reliability of the index for CR is 0.775 .

- The degree to which ICT is a part of students' daily social life (SOIAICT). Examples of statements students responded to are: I like to share information about digital devices with my friends or To learn something new about digital devices, I like to talk about them with my friends. The item reliability of the index for CR is 0.880 .

16 The previous PISA run, i.e. PISA 2012, in contrast, included two sets of questions (and two indexes) focusing on attitudes towards computers (computer as a tool for school learning) (OECD, 2014). 


\subsubsection{ICT competence and autonomy in ICT usage}

Perceived competence and autonomy in ICT use was the focus of the another two questions newly used in PISA 2015. Both questions had the same form as the above described questions focusing on interest in ICT (i.e. respondents expressed their interest or lack of interest using a four-point Likert scale).

- Students' perceived competence in ICT usage (COMPICT). Examples of statements students responded to are: I feel comfortable using digital devices that I am less familiar with or If my friends and relatives have a problem with digital devices, I can help them. The item reliability of the index for CR is 0.858 .

- Students' perceived autonomy related to ICT usage (AUTICT). Examples of statements students responded to are: If I need new software, I install it by myself or If I have a problem with digital devices I start to solve it on my own. The item reliability of the index for $C R$ is 0.821 .

Table 1 Basic descriptive statistics for continuous variables at the student level.

\begin{tabular}{lccccccc} 
& $N$ & Min & Max & \multicolumn{1}{c}{$M$} & \multicolumn{1}{c}{ SD } & Skewness & Kurtosis \\
\hline ICTSCH $^{1}$ & 5800 & 0.00 & 10.00 & 5.68 & 2.07 & 0.02 & 0.17 \\
ICTHOME & 5973 & 0.00 & 11.00 & 8.28 & 1.72 & -0.52 & 0.52 \\
USESCH $^{1}$ & 6330 & -1.67 & 3.63 & 0.27 & 1.03 & 0.46 & 1.84 \\
HOMESCH $^{1}$ & 6239 & -2.69 & 3.60 & 0.13 & 0.95 & 0.39 & 4.35 \\
ENTUSE $^{1}$ & 6382 & -3.71 & 4.84 & 0.17 & 1.03 & 1.14 & 7.60 \\
INTICT $^{1}$ & 6304 & -2.99 & 2.82 & -0.14 & 0.94 & 0.66 & 1.98 \\
SOIAICT $^{1}$ & 6260 & -2.14 & 2.43 & -0.09 & 1.01 & 0.32 & 0.55 \\
COMPICT $^{1}$ & 6262 & -2.66 & 1.97 & -0.1 & 0.96 & 0.25 & 0.28 \\
AUTICT $^{1}$ & 6295 & -2.50 & 2.10 & -0.09 & 0.95 & 0.50 & 0.56 \\
ESCS $^{1}$ & 6716 & -3.01 & 3.49 & -0.19 & 0.79 & 0.11 & -0.23 \\
MATH $^{2}$ & 6812 & 153.74 & 801.74 & 495.93 & 88.21 & -0.03 & -0.18 \\
READ2 $^{2}$ & 6812 & 91.48 & 879.05 & 490.94 & 98.12 & -0.17 & -0.25 \\
SCIE $^{2}$ & 6812 & 139 & 823.97 & 495.84 & 93.87 & 0.04 & -0.39 \\
\hline
\end{tabular}

1 The variable is conceived in such a way that the mean value across OECD countries is 0 and the standard deviation is 1 .

2 The variable is conceived in such a way that the mean value across OECD countries is 500 and the standard deviation is 100 .

Let us conclude this section by noting that the analyses and modelling used also some other variables, mainly as control variables. These included especially the index of economic, social and cultural status (ESCS), ${ }^{17}$ which was used both at the student level and at the school level (ESCS - L2). At the student level the analyses

17 The construction of the index of economic, social and cultural status in PISA surveys is a rather complex issue; for a better insight into how the index is constructed see OECD (2017) or Appendix 4, Indexes and scales, in Blažek \& Boudová (2017). 
50 considered also gender of students (coded by effect coding) and at school level the analyses considered the type of school and an indicator differentiating between state-funded and private schools (PRIVATE). The school type has been coded by dummy coding, with primary school serving as a reference category. The variable PRIVATE has been coded by dummy coding, with state-funded schools serving as a reference category.

\subsection{Data analysis}

Since this study is working with hierarchical data (i.e. students are nested within schools), the analyses are based on multilevel modelling ${ }^{18}$. This is a method increasingly used in recent years not only in educational sciences and in connection with data from ILSA, but also in other disciplines such as sociology, psychology and others (see Hox, 2010; Snijders \& Bosker, 2012; Heck \& Thomas, 2015). The method has not yet found significant application in Czech educational research; a more detailed introduction has been provided especially by Soukup (2006).

Our modelling followed the recommended general strategy proposed by Heck and Thomas (2015) and mentioned by Soukup (2006) while the analysis itself was carried out in statistical environment R (R Core Team, 2017), especially using the BIFIEsurvey package (BIFIE, 2017). As has already been mentioned, the analyses were conducted for each of the areas separately (mathematical, reading and science literacy). The first step involved creating a so-called nullmodel and then a so-called baseline model including only fundamental variables commonly used to explain differences in school performance of students. Only then the models were enriched by ICT-related variables relevant to the research questions, each modelling step only preserving those variables that proved to be statistically significant.

\section{Results}

First for each area of analysis a nullmodel was created as a basis for calculating the intra-class correlation coefficient (ICC). ICC for mathematical literacy was 0.401 , meaning that approximately $40.1 \%$ of the variance of students' school performance can be attributed to differences between schools. ${ }^{19}$ This ICC can be regarded as relatively high, which is in line with the well-known fact that the educational system in the Czech Republic is rather strongly stratified and inter-school differences are relatively high. This has been evidenced by the conclusions of the Czech national report from the most recent survey (Blažek \& Př́hodová, 2016), which also shows

18 International research also refers to this type of analysis as multilevel regression models, hierarchical linear models, mixed-effects models or random-coefficient models (see Heck \& Thomas, 2015).

19 The remaining variance of student performance, i.e. $59.9 \%$, is due to inter-student differences. 
differences in school performance between schools in CR as above-average compared with other OECD countries. ${ }^{20}$ Let us say for the sake of completeness that the remaining two areas have similarly high ICCs. $40.7 \%$ and $40.3 \%$ of the variance can be attributed to inter-school differences in reading literacy and science literacy, respectively.

\subsection{Basic overview of school performance for Czech students}

Table 2 presents the parameters of the baseline two-level models explaining students' performance in the individual areas tested using gender and socioeconomic status at the student level and socioeconomic status at the school level, differentiating between state-funded and private-funded schools of different types. Reflecting the coding used for categorical variables included in the model (see section 3 ), the constant for each model corresponds to the mean performance of students in the given area at a state-funded basic school in CR.

Table 2 Baseline models using basic variables related to the performance of Czech 15-year-olds in tests of mathematical $(M)$, reading $(R)$ and science $(S)$ literacy.

\begin{tabular}{llll}
\hline & Model 1 (M) & Model 1 (R) & Model 1 (S) \\
\hline Fixed effects & coef. (SE) & coef. (SE) & coef. (SE) \\
Intercept & $487.82(3.64)^{* * *}$ & $486.55(4.73)^{* * *}$ & $488.81(4.15)^{* * *}$ \\
ESCS & $22.47(1.74)^{* * *}$ & $21.89(2.45)^{* * *}$ & $20.87(1.8)^{* * *}$ \\
GENDER 1 & $-7.68(1.42)^{* * *}$ & $8.39(1.73)^{* * *}$ & $-8.38(1.41)^{* * *}$ \\
ESCS (L2) & $27.88(6.35)^{* * *}$ & $36.5(7.79)^{* * *}$ & $32.49(6.94)^{* * *}$ \\
PRIVATE & $-18.49(8.08)^{* *}$ & $-21.44(8.4)^{*}$ & $-23.41(8.07)^{* *}$ \\
G8-6 & $82.52(8.2)^{* * *}$ & $74.65(9.51)^{* * *}$ & $88.2(8.29)^{* * *}$ \\
G4 & $73.52(7.6)^{* * *}$ & $77.73(7.91)^{* * *}$ & $76.92(7.53)^{* * *}$ \\
STS & $29.56(5.19)^{* * *}$ & $32.28(6.39)^{* * *}$ & $28.27(5.4)^{* * *}$ \\
SVS & $-35.19(7.43)^{* * *}$ & $-44.76(7.65)^{* * *}$ & $-37.28(7.14)^{* * *}$ \\
Random effects & Variance component & Variance component & Variance component \\
Residual variance & $4085.3(94.2)^{* * *}$ & $5118.3(90.3)^{* * *}$ & $4679.1(52.5)^{* * *}$ \\
Intercept variance & $420.1(80.7)^{* * *}$ & $601.1(105.6)^{* * *}$ & $521.1(92.2)^{* * *}$ \\
Explained proportion of variance & & \\
At the student level & 0.088 & 0.063 & 0.072 \\
At the school level & 0.866 & 0.843 & 0.853 \\
\hline
\end{tabular}

${ }^{*} p<0.05 ;{ }^{* *} p<0.01 ;{ }^{* * *} p<0.001$

1 effect coding

20 Since special and practical schools were excluded from the analyses, inter-school differences are somewhat lower compared with the above-mentioned national report. 
Using the example of performance in mathematics, the coefficient of socioeconomic status at the student level may be interpreted by saying that increasing the index of economic, social and cultural status of a student by one point results in increasing their score in mathematical literacy by 22.47 points. The socioeconomic status at the school level is to be interpreted analogically. The effect of socioeconomic status on student performance is significant. While socioeconomic status at the student level has approximately the same effect on student performance in all areas tested, the effect of socioeconomic status at the school level is stronger for reading and science literacy than for mathematical literacy.

In the context of effect coding, which has been used, the gender coefficient means that girls score by 7.68 points worse than the average student in mathematical literacy and boys score by the same number of points better than the average. Girls are significantly better in terms of reading literacy while boys are better in terms of science literacy again. In all areas analysed, students studying at private-funded schools score significantly worse compared with students at state-funded schools. The coefficient for individual types of school reflects how much better or worse average students in the given type of school perform compared with primary schools.

We regard models in Table 2 as baseline models in the sense of including only the basic parameters commonly used to explain differences in student performance (i.e. socioeconomic status, gender and type of school). The explained proportion of variance at the student level and at the school level in these models will be regarded as reference value. The results obtained from the subsequent models, which will also include ICT-related parameters, will be compared with these baseline models. This will allow us to see to what extent ICT are a factor related to student performance beyond the basic factors included in the baseline models.

\subsection{Performance of Czech students and ICT}

Table 3 presents the basic ICT-related factors which turned to be significant in the individual areas of testing. We can see that in all three areas, the use of ICT by students in school (USESCH) is negatively correlated with their performance. The same holds for the index describing ICT as a part of students' everyday social life (SOIAICT). In contrast, a significantly positive relationship has been found between student performance and perceived autonomy in ICT use (AUTICT). Students who feel to be autonomous/independent in using technologies perform significantly better than other students.

In addition, both reading literacy and science literacy were significantly connected to ICT availability at home (ICTHOME) and use of ICT outside of school for school work (HOMESCH). In both cases however this relationship proves to be (perhaps surprisingly) negative. This means that students who can access ICT tools at home more easily and use them more to prepare for school perform worse in reading and science literacy. 
The use of ICT by students outside of school for entertainment (ENTUSE) has not proved significant in any of the areas analysed. Similarly, no significant differences (with respect to school performance) have been recorded in terms of ICT availability in school (ICTSCH) or perceived competence in ICT use (COMPICT). It is also due to say that none of the variables concerning ICT equipment in school (i.e. numbers of PCs per student or per teacher and numbers of interactive whiteboards and data projectors in school) has proved to be statistically significant with respect to student performance in the individual areas analysed.

A comparison of the explained proportion of variance in the models including ICT-related factors with the above-described baseline models shows that the explained proportion of variance increased from $8.8 \%$ to $17 \%$ at the student level and from $86.6 \%$ to $89.9 \%$ at the school level. The difference therefore is $8.2 \%$ at the student level and $3.3 \%$ at the school level. The situation concerning reading (difference of $10 \%$ at the student level and $3.6 \%$ at the school level) and science (difference of $11.5 \%$ at the student level and $4.1 \%$ at the school level) is similar. This allows us to conclude that the connection between ICT and student performance is stronger at the individual level than at the school level. Also, the relationship between ICT and student performance is the highest in science and the lowest in mathematics.

Table 3 Basic ICT-related variables and performance of Czech 15-year-olds in mathematical (M), reading $(R)$ and science $(S)$ literacy (only significant ICT-related parameters are stated in the table to make it easy to read, although the models included all parameters used in the baseline models).

\begin{tabular}{llll}
\hline & Model 2 $(\mathrm{M})$ & Model $2(\mathrm{R})$ & Model $2(\mathrm{~S})$ \\
\hline Fixed effects & coef. (SE) & coef. $(\mathrm{SE})$ & coef. $(\mathrm{SE})$ \\
Intercept & $495.21(3.07)^{* * *}$ & $517.05(8.58)^{* * *}$ & $524.69(7.73)^{* * *}$ \\
ICTHOME & & $-2.3(0.82)^{* *}$ & $-3.01(0.75)^{* * *}$ \\
HOMESCH & $-5.87(1.75)^{* *}$ & $-6.5(1.64)^{* * *}$ \\
USESCH & $-14.11(1.37)^{* * *}$ & $-15.35(1.77)^{* * *}$ & $-14.43(1.65)^{* * *}$ \\
SOIAICT & $-6.34(1.68)^{* * *}$ & $-6.06(2.01)^{* *}$ & $-5.07(1.69)^{* *}$ \\
AUTICT & $16.47(1.46)^{* * *}$ & $16.63(2.15)^{* * *}$ & $17.63(1.77)^{* * *}$ \\
Random effects & Variance component & Variance component & Variance component \\
Residual variance & $3752.3(88.4)^{* * *}$ & $4571.4(83.3)^{* * *}$ & $4166.4(58.9)^{* * *}$ \\
Intercept variance & $286.5(61.9)^{* * *}$ & $391.8(96.2)^{* * *}$ & $329.5(76.2)^{* * *}$ \\
Explained proportion of variance & & \\
At the student level & 0.17 & 0.163 & 0.187 \\
At the school level & 0.899 & 0.879 & 0.894 \\
\hline
\end{tabular}

${ }^{*} p<0.05 ;{ }^{* *} p<0.01 ;{ }^{* * *} p<0.001$ 


\subsection{Performance of Czech students and internet use}

Table 4 presents models focusing on the use of the internet. All of them concern mathematical literacy. Compared with the previous model, the first model considers the use of the internet at school, the second the use of the internet at home on weekdays, and the third one the use of the internet during weekends. In all cases, the variable reflecting internet use was coded by dummy coding, with zero use or minimum use of the internet as the reference category.

We can see that internet use at school has a statistically significant negative effect for students whose school use of the internet exceeds one hour. Using the internet for over an hour per day at school is associated with worse performance in maths. The situation with internet use at home is however different. Students not using the internet or using it for only up to 30 minutes per day perform significantly worse than students using it for 31 minutes to 6 hours. Students using the internet at home for over 6 hours a day perform the same as students who do not use it at all or only up to 30 minutes a day. It therefore seems that excessive internet use by students (at home) has just as negative impact on their performance as zero or minimal internet use.

Due to the limited space of this article, the following table (table 4) presents only the models made for mathematical literacy. Nevertheless, the results for reading literacy and partly also science literacy were similar. The only exception was the model concerning science literacy and internet use during weekends. The differences in internet use did not prove significant in this case.

Table 4 Frequency of internet use and performance of Czech 15-year-olds in mathematical literacy (the basic parameters applied in the baseline models are not presented, even though they have been included).

\begin{tabular}{llll}
\hline & Model 3a $(M)$ & Model 3b $(M)$ & Model 3c $(M)$ \\
\hline Fixed effects & coef. $(S E)$ & coef. $(S E)$ & coef. $(S E)$ \\
Intercept & $500.41(3.75)^{* * *}$ & $479.93(5.32)^{* * *}$ & $483.07(5.84)^{* * *}$ \\
USESCH & $-11.76(1.34)^{* * *}$ & $-13.39(1.31)^{* * *}$ & $-13.85(1.33)^{* * *}$ \\
SOIAICT & $-6.68(1.66)^{* * *}$ & $-6.1(1.66)^{* * *}$ & $-6.65(1.67)^{* * *}$ \\
AUTICT & $16.95(1.49)^{* * *}$ & $17.03(1.53)^{* * *}$ & $17.08(1.53)^{* * *}$ \\
Internet at school: & $-1.7(3.34)$ & & \\
1 to 30 minutes & $-2.83(4.43)$ & & \\
31 to 60 minutes & $-10.05(3.95)^{*}$ & & \\
1 to 4 hours & $-29.24(5.82)^{* * *}$ & & \\
over 4 hours & & $23.28(5.48) * * *$ \\
Internet at home: & & $22.12(5.3) * * *$ \\
31 mins to 2 hours & & $13.44(5.59) *$ & \\
2 to 4 hours & & $0.29(6.2)$ & \\
4 to 6 hours & &
\end{tabular}


Internet on weekends:

31 mins to 2 hours

$15.11(6.25)$ *

2 to 4 hours

$19.6(6.63)$ **

4 to 6 hours

$16.91(6.11)^{* *}$

over 6 hours

3.58 (6.02)

\section{Random effects}

Residual variance

Variance component

$3683.3(87.4) * * *$

Variance component

$270.9(59.1)^{* * *}$
$3663.2(85.1)^{* * *}$

$262.3(58.9) * * *$
Variance component $3689.8(84.4) * * *$

$275.8(62.6) * * *$

\section{Explained proportion of variance}

$\begin{array}{llll}\text { At the student level } & 0.189 & 0.192 & 0.185 \\ \text { At the school level } & 0.904 & 0.906 & 0.902\end{array}$

${ }^{*} p<0.05 ;{ }^{* *} p<0.01 ;{ }^{* * *} p<0.001$

\subsection{ICT in interactions}

Finally, we have analysed whether the relationship between the analysed ICT-related variables and student performance in mathematical, reading and science literacy is moderated by other variables. Due to the limited space, we only report selected results of the interaction analysis. Table 5 presents 3 different models addressing interactions with gender and type of school.

Table 5 Models with interactions (not all baseline models' parameters are presented, to keep the table easy to read).

\begin{tabular}{|c|c|c|c|}
\hline & Model $4(M)$ & Model 5 (R) & Model 6 (S) \\
\hline Fixed effects & coef. (SE) & coef. (SE) & coef. (SE) \\
\hline Intercept & $495.27(3.08) * * *$ & $515.4(8.73)$ *** & $525.59(7.69)$ *** \\
\hline ICTHOME & & $-2.25(0.82) * *$ & $-3.05(0.75)^{* * *}$ \\
\hline HOMESCH & & $-6(1.76) * *$ & $-6.43(1.67)^{* * *}$ \\
\hline SOIAICT & $-6.54(1.67) * * *$ & $-7.05(2.04) * *$ & $-5.08(1.69)$ ** \\
\hline AUTICT & $15.95(1.54)^{* * *}$ & $14.16(2.41)^{* * *}$ & $17.57(1.76)^{* * *}$ \\
\hline GENDER & $-7.18(1.65)^{* * *}$ & $7.78(1.74) * * *$ & $-7.56(1.47)^{* * *}$ \\
\hline INTICT & $0.48(1.7)$ & & \\
\hline GENDER $\times$ INTICT & $-2.36(1.17)$ * & & \\
\hline СОMPICT & & $3.05(1.87)$ & \\
\hline GENDER $\times$ COMPICT & & $-4.29(1.41)^{* *}$ & \\
\hline USESCH & $-14.43(1.35) * * *$ & $-15.36(1.78) * * *$ & $-16.91(2.11)$ *** \\
\hline SVS & $-27.63(7.23)^{* * *}$ & $-31.66(7.41)^{* * *}$ & $-26.5(7.08)^{* * *}$ \\
\hline SVS $\times$ USESCH & & & $6.76(2.94)$ * \\
\hline STS & $28.45(4.76){ }^{* * *}$ & $30.04(5.93)^{* * *}$ & $24.94(5.02)^{* * *}$ \\
\hline
\end{tabular}


$\mathrm{STS} \times \mathrm{USESCH}$

G4

G4 $\times$ USESCH

GV

$\mathrm{GV} \times$ USESCH

Random effects

Residual variance

Intercept variance
$70.01(7.25) * * *$

$76.5(7.57) * * *$

Variance component

$3735.9(85.9) * * *$

$290.5(64.9)$ ***
$6.6(2.51)^{* *}$

$70.71(6.9)$ ***

$7.72(3)$ *

$78.46(7.7) * * *$

-0.42 (3.98)

Variance component

4153.9 (58.2) ***

$329.7(77.4)$ ***

Explained proportion of variance

$\begin{array}{llll}\text { At the student level } & 0.172 & 0.168 & 0.191 \\ \text { At the school level } & 0.897 & 0.881 & 0.894\end{array}$

${ }^{*} p<0.05 ;{ }^{* *} p<0.01 ;{ }^{* * *} p<0.001$

It turned out above all that although initially interest in ICT (INTICT) and perceived ICT competence (COMPICT) did not seem to be significant factors, they turned out to be significant (in some cases) after including the interaction with gender. The relationship between ICT interest and student performance (Model 4) as well as the relationship between perceived ICT competence and student performance (Model 5) are significantly moderated by gender. In both cases high interest in ICT and high perceived ICT competence are associated with better results for boys and the trend tends to be opposite for girls. The decrease for girls is however milder than the increase for boys. Another interesting finding is that while the interaction between ICT interest and gender was significant only in connection with mathematical literacy (Model 4), the interaction between gender and perceived ICT competence was significant in all three areas of analysis (although Table 5 shows only the model for reading, i.e. Model 5).

The last of the models (Model 6) addresses the interaction between ICT use in school (USESCH) and type of school. Here, too, the analysed interaction proved significant, meaning that the relationship between ICT use at school and students' performance varies significantly depending on the type of school. It is true for all types of school that higher USESCH scores are associated with worse school performance, but the relationship is considerably stronger for primary schools and 8-year and 6-year gymnasiums than other types of school. This means that the worsening of school performance with increasing ICT use at school gets more serious with these two types of school.

\section{Discussion}

The results of the analyses allow us to conclude that neither ICT availability at school nor ICT equipment available at school seem to have a direct effect on student 
performance. This finding may be regarded as a rather expectable one (also see the European Schoolnet research, 2013). As we have said in Section 1, most of the activities concerning ICT in education so far have addressed equipping schools with technologies and making sure that a basic level of availability of digital technologies will be the case in all schools. It therefore seems that a certain basic level of technology availability has been provided in Czech schools and the now existing differences in technologies available are not so pronounced any more to have a direct effect on student performance. This does not naturally mean that technological equipment in schools and ICT availability has ceased to be an important topic. The issue is, firstly, still topical due to the fast ageing of modern technologies (ČŠI, 2009, 2017b) and, secondly, technological availability is a basic prerequisite for technologies to be used in schools. Therefore, although their availability does not influence students' school performance directly, it still is an indirect influence.

One rather surprising finding concerning ICT availability is that ICT availability at home proved to be significant. It is firstly surprising that it turned out to be significant only in connection to performance in reading and science literacy but not in connection with mathematical literacy, and, secondly, because its effect on students' performance was negative. We are not able to explain this unequivocally and this topic will need to be further researched. The supplementary analyses, which unfortunately could not be fully described in this paper, however indicate that two factors might be at play. 1) The PISA questionnaire conceives the question concerning ICT availability not only in terms of its physical presence in students' homes but, to some extent, in terms of its use. 2) ICT availability at home seems to be moderated by the student's family's socioeconomic status, where for students with higher ESCS index greater ICT availability at home is related to better performance and for students with lower ESCS index with worse performance. It is therefore possible that the ICT availability index partly reflects ICT use by students while ways of ICT use by students vary depending on the socioeconomic status of the student's family. This would be in agreement with partial results of Czech School Inspectorate's secondary analysis (ČŠI, 2016), which identified certain differences in ICT use by students from families with varying socioeconomic status.

As for ICT use by students, attention was paid to their use of ICT at school and outside of school for school work and for leisure activities. As for ICT use at home, as it was to be expected, there was no significant link between ICT use in leisure time and school performance. In contrast, a rather surprising finding was the negative link between students' school performance and their ICT use at home for school work (such as doing homework using the PC etc.). Some supplementary analyses will need to be performed to explain this link. The results of the analyses made so far however do not indicate that this relationship has to do with the student's gender or socioeconomic status of their family. It is also due to say that the significantly negative effect of ICT use at home for school work was reflected only in terms of reading and science literacy. 
A less surprising finding was the negative link between ICT use at school and students' school performance. Hints of this relationship occurred already in PISA data international analyses from previous years (OECD, 2015) as well as in the secondary analysis of PISA 2012 data by the Czech School Inspectorate (2016). To understand and explain the negative effect of ICT use in school on students' school performance, one primarily needs to be aware of how this index is conceived in PISA surveys. Rather than a measure of how (much) ICT are used in the given school, it is a measure of how (much) the given student uses ICT at school. It therefore reflects individual use of ICT by the student, which need not necessarily correspond to how ICT are used in the school as a whole. This is consistent with the partial results of the analyses, where the ICT use index aggregated at the school level did not seem significant. What also could play a role is the way respondents are selected as PISA surveys do not consider the level of the class (Straková, 2016). However, ICT use at school may differ significantly depending on the specific class and teacher. It has also turned out that the relationship between ICT use at school and students' school performance is significantly moderated by type of school, this negative relationship being stronger in primary schools and 8-year and 6-year gymnasiums. Thus, a broader context seems to play an important role in ICT use by students as well.

Moreover, the index of ICT use at school includes relatively general components not concerning ICT directly for school-related activities (the questionnaire, for instance, features items such as Chatting online at school or Using email at school). It is therefore easy to imagine that even students who do not pay attention to the learning content in class may have a high index of ICT use at school, chatting online with friends instead. Other items included in the index concern e.g. practising learning content or doing homework using a school PC, which are also likely to be more frequent with less successful students. Underperforming students may simply need to learn more at school (including using PC) and/or may try to catch up with homework at school after they have not given it enough time at home. This seems to be in line with the partial results of the secondary analysis by the Czech School Inspectorate (2016), according to which students from successful schools use school computers to practise learning content less. It may however also be that insufficient training of teachers for efficient ICT use in class also plays a role. This would be consistent with the results of TALIS 2013 research, which suggest that ICT skills are one of the most demanded topics in professional training of Czech teachers while the greatest proportion of Czech teachers call for more professional training in ICT skills for teaching (Kašparová, Boudová, Ševců, \& Soukup, 2014). Inadequate skills among teachers were also indicated in research by Zounek and Šed'ová (2009), according to which teachers tend to use ICT to reward students for working well in class and use them for their own teaching to a much smaller extent.

Besides ICT use in general, we have analysed the use of the internet by students during an ordinary day, at school, at home on a weekday, and at home on weekends. The results are, again, largely consistent with what we know from PISA 2012 survey (ČŠI, 2016; OECD, 2015). Attention so far has largely been paid to the negative ef- 
fect excessive internet use has on student performance. The results of our analyses however indicate that excessive use of the internet (over 6 hours per day) at home is associated with the same - meaning equally bad - performance at school as minimum internet use (up to 30 minutes). The simple rule "The more internet at home, the worse performance at school" is thus not valid. Worse performance seems to be associated with "extreme" uses of the internet, at both ends of the range (i.e. too much and too little). The situation regarding the use of the internet at school is different: it indeed seems that the more students use the internet at school, the worse they perform. The explanation may however again be that using internet at school is a general label including not only internet use for learning but potentially conflicting with it (i.e. students may use the internet instead of paying attention to what they should be learning).

Finally, there were two variables concerning interest in ICT (i.e. INTICT and SOIAICT) and variables concerning ICT competence (COMPICT) and ICT autonomy (AUTICT) which were included in the analyses. These were however indexes newly introduced in PISA 2015, which cannot be simply related to the results from previous years. These variables have not been addressed by reports publishing results of PISA 2015 so far (see OECD, 2017a, 2017b, 2017c), therefore a basic comparison with countries included in PISA surveys is not possible. Nevertheless, focusing first on ICT competence and ICT autonomy, somewhat surprising is the strong positive relationship between students' autonomy in ICT use and their performance in tests of mathematical, reading and science literacy. This link may be due to the fact that better-performing students can generally work in more autonomous ways, which gets reflected in their autonomy in using digital technologies. Autonomy in ICT use, however, also requires some competence in using technologies; it was therefore rather surprising that the index of perceived ICT competence initially did not seem significant. A more detailed analysis however revealed that the connection between ICT competence and school performance varies significantly depending on gender. While the relationship is positive for boys (i.e. higher competence is related to better results) the relationship is mildly negative for girls.

The same is true of ICT interest, but only in connection to performance in mathematical literacy. Explanation for these findings may be found on the basis of ICILS survey results (Basl, Bird, Boudová, \& Tomášek, 2015; Basl, Boudová, \& Řezáčová, 2014; Fraillon, Ainley, Schulz, Friedman, \& Gebhardt, 2014), according to which girls did perform better at tests of computer and information literacy while their competencies in terms of advanced skills were assessed as worse. It was also boys rather than girls who expressed interest in ICT. It therefore seems that there are major differences between girls and boys in CR concerning interest in ICT, perceived ICT competencies and their effect on school performance. Last but not least, a rather surprising result is the negative correlation between the extent modern technologies play a role in everyday lives of students (SOIAICT) and school performance of students in all three researched areas. Unfortunately, in this case a comparison with other countries included in PISA surveys has not been available either nor are 
60 more detailed analyses which could help explain the identified relationship more thoroughly.

\section{Conclusions}

Our study capitalizes on one of the opportunities provided by using data from ILSA to get a deeper insight into ICT in the context of the Czech educational system. We believe that the results of our analyses may yield important information for national educational policies on ICT, where the missing research and evaluation of the impact of ICT use on school education has been among the key problems.

Besides the results as such, we believe that our study illustrates also general possibilities of secondary ILSA analyses while pointing out also some of their limitations. Due to the rather broad focus of the study, its outputs include a series of new questions calling for more attention of research. Follow-up research could, for instance, address supplementary analyses of PISA data focusing on more specific questions concerning digital technologies. Another option is to use ICILS 2013 data, which has not been fully used in the Czech context yet. Our view is that these quantitative analyses should also be supplemented with qualitative research, which may mediate a better understanding of the contexts of ICT use by individuals at school and at home. Our further research therefore aims to go in this direction as well.

Last but not least it is due to mention the need for a specifically focused national survey to address not only links between ICT use by students and their school performance (measured in a traditional way). We believe that with respect to the so called competencies for the 21st century, attention should also be paid to whether and to what extent modern technologies can play a role in situations when students must combine their technological knowledge and skills with critical thinking, ability to work in teams and communicating with other actors (at school and beyond school) or come up with out-of-the-box and creative solutions to problems.

\section{Acknowledgements}

The study is one of the outputs of research project "Digital technologies in students' everyday lives and learning", supported by the Czech Science Agency (Grant no. 17-06152S). The authors express their thankfulness for the support.

\section{References}

Basl, J. (2010). Diferenciace $v$ počítačové gramotnosti a nerovnosti $v$ přístupu $k$ informačním technologiím [Differentiation in computer literacy and inequalities in access to information technologies]. In P. Matějů, J. Straková, \& A. Veselý (Eds.), Nerovnosti ve vzdělávání: Od 
měření k řešení [Inequalities in education: From measurement to solutions] (pp. 208-226). Praha: Sociologické nakladatelství (SLON).

Basl, J. (2014). Statistika ve školství: Eurostat, OECD, PISA, IEA. In J. Hendl, et al., Statistika $\checkmark$ aplikacích [Statistics in applications] (pp. 287-304). Praha: Portál.

Basl, J., Bird, L., Boudová, S., \& Tomášek, V. (2015). Mezinárodní šetření ICILS 2013: Shody a rozdíly $v$ počítačové a informační gramotnosti mezi vybranými evropskými zeměmi [International ICILS 2013 survey: Coincidences and differences in computer and information literacy between selected European countries]. Praha: Česká školní inspekce. Retrieved from http://www.csicr.cz/html/ICILS2013-ShodyRozdily/flipviewerxpress.html.

Basl, J., Boudová, S., \& Řezáčová, L. (2014). Národní zpráva šetření ICILS 2013: Počitačová a informační gramotnost českých žáků [National report of ICILS 2013 survey: Computer and information literacy of Czech students]. Praha: Česká školní inspekce. Retrieved from http://www.csicr.cz/html/ICILS2013-NarodniZprava/flipviewerxpress.html

Biagi, F., \& Loi, M. (2013). Measuring ICT use and learning outcomes: Evidence from recent econometric studies. European Journal of Education, 48(1), 28-42. https://doi.org/10.1111 /ejed.12016

BIFIE (2017). BIFIEsurvey: Tools for survey statistics in educational assessment. R package version 2.3-18. https: / /CRAN.R-project.org/package=BIFIEsurvey

Blažek, R. \& Boudová, S. (2017). Národní zpráva PISA 2015: Týmové řešení problému, dotazníkové šetření [PISA 2015 national report: Teamwork on the problem, questionnaire survey]. Praha: Česká školní inspekce. Retrieved from http://www.csicr.cz/html/PISA_2015_NZ _reseni_problemu/flipviewerxpress.html.

Blažek, R., \& Příhodová, S. (2016). Mezinárodní šetření PISA 2015: Národní zpráva. [PISA 2015 international survey: National report] Praha: Česká školní inspekce.

Caha, Z. (1986). Elektronizace ve výchově a vzdělávání [Electronization in education and upbringing]. Pedagogika, 36(2), 133-136.

Comi, S. L., Argentin, G., Gui, M., Origo, F., \& Pagani, L. (2017). Is it the way they use it? Teachers, ICT and student achievement. Economics of Education Review, 56, 24-39. https: // doi.org/10.1016/j.econedurev.2016.11.007

Cox, M. J., \& Marshall, G. (2007). Effects of ICT: Do we know what we should know? Education and Information Technologies, 12(2), 59-70. https: //doi.org/10.1007/s10639-007-9032-x.

ČŠI. (2009). Úroveň ICT v základních školách $\vee$ ČR: Tematická zpráva [ICT level in primary schools in CR: Thematic report]. Retrieved from http://www.csicr.cz/html/ICTvZS /flipviewerxpress.html.

ČŠı. (2013). Výroční zpráva české školní inspekce za školní rok 2011/2012 [Czech School Inspectorate annual report for 2011/2012]. Praha: Česká školní inspekce. Retrieved from http://www.csicr.cz/html/vzcsi_2011_12/flipviewerxpress.html.

ČŠI. (2016). Žáci a ICT: Sekundární analýza výsledků mezinárodních šetření ICILS 2013 a PISA 2012 [Secondary analysis of ICILS 2013 and PISA 2012 international surveys]. Praha: Česká školní inspekce.

ČŠl. (2017a). Kvalita a efektivita vzdělávání a vzdělávací soustavy ve školním roce 2016/2017: Výroční zpráva české školní inspekce [Quality and effectivity of the educational system in 2016/2017: Czech School Inspectorate annual report]. Praha: Česká školní inspekce. Retrieved from http://www.csicr.cz/html/Vyrocni_zprava_CSI_2016_2017/flipviewerxpress .html.

ČŠı. (2017b). Využívání digitálních technologií v mateřských, základních, středních a vyšších odborných školách: Tematická zpráva [The use of technologies in kindergartens, basic, secondary and higher vocational schools: Thematic report]. Retrieved from http://www .csicr.cz/html/tz_digitechnologie/flipviewerxpress.html.

Erdogdu, F., \& Erdogdu, E. (2015). The impact of access to ICT, student background and school/home environment on academic success of students in turkey: An international comparative analysis. Computers \& Education, 82, 26-49. https://doi.org/10.1016/j .compedu.2014.10.023 
62 European Schoolnet. (2015). Czech Republic. Country report on ICT in education. Retrieved from http://www.eun.org/cs/resources/country-reports.

European Schoolnet (2013). Survey of Schools: ICT in Education. Benchmarking access, use and attitudes to technology in Europe's schools. Final Report. Retrieved from https:// ec.europa.eu/digital-agenda/sites/digital-agenda/files/KK-31-13-401-EN-N.pdf.

Falck, O., Mang, C., \& Woessmann, L. (2017). Virtually no effect? Different uses of classroom computers and their effect on student achievement. Oxford Bulletin of Economics and Statistics, 80(1), 1-38. https://doi.org/10.1111/obes.12192

Fraillon, J., Ainley, J., Schulz, W., Friedman, T., \& Gebhardt, E. (2014). Preparing for life in a digital age: The IEA international computer and information literacy study international report. Springer International Publishing. https: / / doi.org/10.1007/978-3-319-14222-7

Heck, R. H., \& Thomas, S. L. (2015). An introduction to multilevel modeling techniques: MLM and SEM approaches using Mplus. New York, NY: Taylor \& Francis.

Hox, J. J. (2010). Multilevel Analysis: Techniques and Applications. New York, NY: Routledge. Kašparová, V., Boudová, S., Ševců, M., \& Soukup, P. (2014). Národní zpráva šetření Talis 2013 [Talis 2013 survey, national report]. Praha: Česká školní inspekce. Retrieved from http: // www.csicr.cz/html/TALIS2013-NZ/ flipviewerxpress.html.

Kubiatko, M., \& Vlčková, K. (2010). The relationship between ICT use and science knowledge for Czech students: A secondary analysis of PISA 2006. International Journal of Science and Mathematics Education, 8(3), 523-543. https://doi.org/10.1007/s10763-010-9195-6.

Lei, J. (2010). Quantity versus quality: A new approach to examine the relationship between technology use and student outcomes. British Journal of Educational Technology, 41(3), 455-472. https://doi.org/10.1111/j.1467-8535.2009.00961.x

Leuven, E., Lindahl, M., Oosterbeek, H., \& Webbink, D. (2007). The effect of extra funding for disadvantaged pupils on achievement. Review of Economics and Statistics, 89(4), 721-736. https://doi.org/10.1162/rest.89.4.721

Luu, K., \& Freeman, J. G. (2011). An analysis of the relationship between information and communication technology (ICT) and scientific literacy in Canada and Australia. Computers \& Education, 56(4), 1072-1082. https://doi.org/10.1016/j.compedu.2010.11.008

Matějů, P., \& Simonová, N. (2013). Koho znevýhodňuje škola: Chlapce, nebo dívky? Rozdíly $\checkmark$ dovednostech, školních výsledcích a vzdělanostních aspiracích dívek a chlapců devátých tříd základních škol [Who is disadvantaged by school? Boys, or girls? Differences in skills, school performance and educational aspirations of girls and boys in Grade 9 of primary schools]. Orbis Scholae, 7(3), 107-138.

Matějů, P., \& Straková, J. (2006). (Ne)rovné šance na vzdělání: Vzdělanostní nerovnosti $\checkmark$ České republice [(Un)equal educational chances: Educational inequality in the Czech Republic]. Praha: Academia.

Matějů, P., Straková, J., \& Veselý, A. (2010). Nerovnosti ve vzdělávání: Od měření k řešení [Inequalities in education: From measurements to solutions]. Praha: Sociologické nakladatelství (SLON).

Michek, S., Vondroušová, J., \& Vítová, J. (Eds.). (2017). Vliv technologií v oblasti vzdělávání a v pedagogickém výzkumu: Sborník abstraktů z XXV. Konference České asociace pedagogického výzkumu konané ve dnech 13.-14. záři 2017 v Hradci Králové [The impact of technologies in education and pedagogical research]. Hradec Králové: Gaudeamus.

MPO. (n.d.). Digitální Česko v. 2.0, cesta k digitální ekonomice [Digital Czechia v. 2.0, pathway to digital economy]. Retrieved from https://www.mpo.cz/assets/cz/e-komunikace -a-posta/Internet/2013/4/Digi_esko_v.2.0.pdf.

MŠMT. (2014). Strategie digitálního vzdělávání do roku 2020 [Strategy for digital education until 2020]. Retrieved from http://www.msmt.cz/file/34429.

MŠMT. (2017). Průběžné hodnocení implementace Strategie digitálního vzdělávání do roku 2020 (rok 2016) [Ongoing evaluation of the implementation of the Strategy for digital education until 2020; 2016]. Retrieved from http: / /www.msmt.cz/uploads/Implementace _SDV_zprava_za_rok_2016.pdf. 
MŠMT. (2018). Průběžné hodnocení implementace Strategie digitálního vzdělávání do roku 2020 (rok 2017) [Ongoing evaluation of the implementation of the Strategy for digital education until 2020; 2017]. Retrieved from http://www.msmt.cz/uploads/zpra_va_SDV _vla_da_2017.docx.

OECD. (2005). Are students ready for a technology-rich world? What PISA studies tell us. Paris: OECD Publishing. Retrieved from http://www.oecd.org/education/school/programmeforinternationalstudentassessmentpisa/35995145.pdf.

OECD. (2011). PISA 2009 Results: Students on line. Paris: OECD Publishing. Retrieved from https://doi.org/10.1787/9789264112995-en.

OECD. (2014). PISA 2012 Technical report. Paris: OECD Publishing. Retrieved from https:// www.oecd.org/pisa/pisaproducts/PISA-2012-technical-report-final.pdf.

OECD. (2015). Students, computers and learning: Making the connection. Paris: OECD Publishing. Retrieved from https://doi.org/10.1787/9789264239555-en.

OECD. (2017a). PISA 2015 Results (Volume I): Excellence and Equity in Education. Paris: OECD Publishing. Retrieved from http://dx.doi.org/10.1787/9789264266490-en.

OECD. (2017b). PISA 2015 Results (Volume II): Policies and Practices for Successful Schools. Paris: OECD Publishing. Retrieved from http://dx.doi.org/10.1787/9789264267510-en.

OECD. (2017c). PISA 2015 Results (Volume III): Students' Well-Being. Paris: OECD Publishing. Retrieved from https://doi.org/10.1787/9789264273856-en.

OECD. (2017d). PISA 2015 Technical report. Paris: OECD Publishing. Retrieved from http:// www.oecd.org/pisa/sitedocument/PISA-2015-technical-report-final.pdf.

Palečková, J., Tomášek, V., \& Basl, J. (2010). Hlavní zjištění výzkumu PISA 2009. Umíme ještě čist? [Principal findings of PISA 2009 survey. Can we still read?]. Praha: Ústav pro informace ve vzdělávání.

Ponzo, M. (2011). Does the way in which students use computers affect their school performance? Journal of Economic \& Social Research, 13(2), 1-27.

Potužníková, E., Lokajíčková, V., \& Janík, T. (2014). Mezinárodní srovnávací výzkumy školního vzdělávání v České republice: Zjištění a výzvy [International comparative studies on school education in the Czech Republic: Findings and challenges]. Pedagogická Orientace, 24(2), 185-221. https://doi.org/10.5817/PedOr2014-2-185

R Core Team (2017). R: A language and environment for statistical computing. R Foundation for Statistical Computing, Vienna, Austria. https://www.R-project.org/

Skryabin, M., Zhang, J., Liu, L., \& Zhang, D. (2015). How the ICT development level and usage influence student achievement in reading, mathematics, and science. Computers \& Education, 85, 49-58. https://doi.org/10.1016/j.compedu.2015.02.004

Snijders, T. A. B., \& Bosker, R. J. (2012). Multilevel analysis: An introduction to basic and advanced multilevel modeling. Thousand Oaks, CA: Sage Publications.

Soukup, P. (2006). Proč užívat hierarchické lineární modely? [Why use hierarchical linear models?]. Sociologický časopis/Czech Sociological Review, 42(5), 987-1012.

Soukup, P. (2012). Mezinárodní výzkumy v oblasti vzdělávání [International surveys in education]. In J. Krejčí \& Y. Leontiyeva (Eds.), Cesty $k$ datům: Zdroje a management sociálněvědních dat v České republice (pp. 302-324). Praha: Sociologické nakladatelství (SLON).

Soukup, P. (2016). Možnosti praktické práce s daty z mezinárodních vzdělávacích studií: Problémy a jejich praktická řešení [Possibilities of practical work with data from international large scale educational assessments: problems and practical solutions]. Orbis Scholae, 10(1), 97-120. https://doi.org/10.14712/23363177.2016.15

Spiezia, V. (2010). Does computer use increase educational achievements? Student-level evidence from PISA. OECD Journal: Economic Studies, 2010(7), 1-22. https://doi.org/10.1787 /eco_studies-2010-5km33scwlvkf

Straková, J. (2009). Vzdělávací politika a mezinárodní výzkumy výsledků vzdělávání v ČR [Educational policies and international surveys of educational outcomes in CR]. Orbis Scholae, 3(3), 103-118. https://doi.org/10.14712/23363177.2018.200

Straková, J. (2010). Dopad diferenciace vzdělávacích príležitostí v povinném vzdělávání na vývoj nerovností ve výsledcích žáků v ČR po roce 2000 [The impact of differentiation of 
educational opportunities in compulsory education on the development of inequality in pupils' results in the CR since 2000]. Pedagogika, 60(2), 21-37.

Straková, J. (2016). Mezinárodní výzkumy výsledků vzdělávání: Metodologie, prínosy, rizika a príležitosti [International surveys of educational outcomes: methodologies, merits, risks and opportunities]. Praha: Univerzita Karlova v Praze, Pedagogická fakulta.

Sucháček, P. (2014). Spor o víceletá gymnázia: Historický kontext a empirická data [The dispute about classical grammar schools: Historical context and empirical data]. Studia Paedagogica, 19(3), 139-154. https://doi.org/10.5817/SP2014-3-8

Woessmann, L., \& Fuchs, T. (2004). Computers and student learning: Bivariate and multivariate evidence on the availability and use of computers at home and at school. CESifo Working Paper Series No. 1321. Retrieved from https: //ssrn.com/abstract=619101

Wittwer, J., \& Senkbeil, M. (2008). Is students' computer use at home related to their mathematical performance at school? Computers \& Education, 50(4), 1558-1571. https://doi .org/10.1016/j.compedu.2007.03.001

Zounek, J., \& Šed'ová, K. (2009). Učitelé a technologie: Mezi tradičním a moderním pojetím [Teachers and technologies: Between the traditional and the modern approach]. Brno: Paido.

Zounek, J., \& Tůma, F. (2014). Problematika ICT ve vzdělávání v českých pedagogických časopisech (1990-2012) [Issues related to ICT in education from the perspective of Czech educational journals (1990-2012)]. Studia Paedagogica, 19(3), 65-87. Retrieved from http://www.phil.muni.cz/journals/index.php/studia-paedagogica/article/view/902.

Mgr. Bc. Libor Juhaňák

Department of Educational Sciences Faculty of Arts, Masaryk University Arne Nováka 1, 60200 Brno juhanak@phil.muni.cz

Assoc. Prof. Mgr. Jiří Zounek, Ph.D. Department of Educational Sciences Faculty of Arts, Masaryk University Arne Nováka 1, 60200 Brno zounek@phil.muni.cz

Mgr. Klára Záleská Department of Educational Sciences Faculty of Arts, Masaryk University Arne Nováka 1, 60200 Brno zaleska@phil.muni.cz

Mgr. Ondřej Bárta Department of Educational Sciences Faculty of Arts, Masaryk University Arne Nováka 1, 60200 Brno barta@phil.muni.cz

Mgr. Kristýna Vlčková Department of Educational Sciences Faculty of Arts, Masaryk University Arne Nováka 1, 60200 Brno vlckova.k@mail.muni.cz 